Kansas State University Libraries

New Prairie Press

Academic Chairpersons Conference

37th Academic Chairpersons Conference,

Proceedings

Savannah, GA

\title{
Feedback: The Foundation of Kind Leadership
}

Rebecca L. Koltz

Montana State University, rebecca.koltz@montana.edu

Melissa Odegard

Southeast Missouri State University, Modegard@semo.edu

Follow this and additional works at: https://newprairiepress.org/accp

Part of the Educational Leadership Commons, and the Higher Education Administration Commons

(c) (i)

This work is licensed under a Creative Commons Attribution 4.0 License.

\section{Recommended Citation}

Koltz, Rebecca L. and Odegard, Melissa (2020). "Feedback: The Foundation of Kind Leadership," Academic Chairpersons Conference Proceedings. https://newprairiepress.org/accp/2020/leadership/12

This Event is brought to you for free and open access by the Conferences at New Prairie Press. It has been accepted for inclusion in Academic Chairpersons Conference Proceedings by an authorized administrator of New Prairie Press. For more information, please contact cads@k-state.edu. 
Kindness in leadership does not parallel weakness. Kind leadership recognizes that feedback is an important part of the relationship. Brown (2018) states that unclear feedback to employees is unkind. However, a challenge presents with understanding as the leader how to deliver honest, kind feedback in the context of higher education. In fact, feedback in higher education is considered a tenuous issue at best; however, to avoid surprises, frequent evaluation and feedback should occur (Kramer, 2019). Frequent feedback can promote personal development and reinforce the type of employee performance that will lead to success.

For this presentation, we will unpack common misconceptions regarding feedback and situate how to deliver feedback to employees using a group facilitation tool- Johari's Window. This tool, originally developed by Joseph Luft and Harry Ingham (1955), was developed to increase communication and awareness. It is used to build trust through honest and direct communication. Johari's Window operates using four quadrants: Open, Hidden, Blind Area, and Unknown. Each quadrant will be explained and situated in the Chairperson's context. Faculty case examples and role playing will be used to demonstrate how to implement the communication model in their departments. We will invite Chairs to consider work scenarios where feedback has been challenging with faculty in their departments. Furthermore, ideas will be shared for how to situate the model in individual, as well as group to foster a culture of kind leadership in their home departments.

Brown, Brene (2018) Dare to lead: Brave work, tough conversations, whole hearts. New York, NY: Random House.

Kramer, R. (2019) The art of executive feedback. The Chronicle of Higher Education. Retrieved from https://www.chronicle.com/article/The-Art-of-Executive-Feedback/245730

Luft, J. \& Ingham, H. (1955) The Johari window: A graphic model for interpersonal relations, University of California Western Training Lab. 